\title{
KOMPENSASI DAN LINGKUNGAN KERJA: PENGARUHNYA TERHADAP KINERJA KARYAWAN
}

\author{
Gede Ardi Putra Kresmawan ${ }^{1}$ \\ I Gede Putu Kawiana ${ }^{2}$ \\ I Gede Aryana Mahayasa ${ }^{3}$ \\ 1,2,3 Program Studi Manajemen Fakultas Ekonomi Bisnis dan Pariwisata Universitas Hindu Indonesia \\ ${ }^{3}$ corresponding author: email: aryanamahayasa@gmail.com
}

\section{How to cite (in APA style):}

Gede Ardi Putra Kresmawan, I Gede Putu Kawiana, dan I gede Aryana Mahayasa. (2021). Kompensasi dan Lingkungan Kerja: Pengaruhnya Terhadap Kinerja Karyawan. Warmadewa Management and Business Journal, 3(2) pp.75-84

\begin{abstract}
Human resource development is needed to improve employee performance, especially at PT. Inti Dufree Promosindo. The purpose of this study to determine the effect partially and simultaneously compensation and work environment on employee performance at PT. Inti Dufree Promosindo in Denpasar. The population in this study were all employees of PT. Inti Dufree Promosindo in Denpasar as many as 86 people who are divided into 6 shop sections, namely Beauty, Boutique, Fashion Watch, Fine Watch, Food \& Liqueur, and Destination. Determination of the sample using saturated sampling technique, where the entire population is sampled. After the instrument test and classical assumption test were carried out, data analysis was carried out using multiple linear regression analysis, determination, $t$ test, and $F$ test. The results of the analysis showed that compensation had a positive and significant effect on employee performance. The work environment has a positive and significant effect on employee performance. Compensation and work environment simultaneously have a positive and significant effect on employee performance at PT. Inti Dufree Promosindo in Denpasar.
\end{abstract}

Keywords: Compensation, Work Environment, Employee Performance

\begin{abstract}
ABSTRAK
Pengembangan sumber daya manusia sangat diperlukan untuk meningkatkan kinerja karyawan khususnya pada PT. Inti Dufree Promosindo. Tujuan penelitian ini untuk mengetahui pengaruh secara parsial dan simultan kompensasi dan lingkungan kerja terhadap kinerja karyawan pada PT. Inti Dufree Promosindo di Denpasar. Populasi dalam penelitian ini adalah seluruh karyawan PT. Inti Dufree Promosindo di Denpasar sebanyak 86 orang yang terbagi dalam 6 seksi ruko, yaitu: Kecantikan, Butik, Jam Tangan Fashion, Jam Tangan Mewah, Makanan \& Minuman Keras, dan Tempat Tujuan. Penentuan sampel menggunakan teknik sampling jenuh, dimana seluruh populasi dijadikan sampel. Setelah dilakukan uji instrumen dan uji asumsi klasik, dilakukan analisis data dengan menggunakan analisis regresi linier berganda, determinasi, uji t, dan uji F. Hasil analisis menunjukkan bahwa kompensasi berpengaruh positif dan signifikan terhadap kinerja karyawan. Lingkungan kerja berpengaruh
\end{abstract}


positif dan signifikan terhadap kinerja karyawan. Kompensasi dan lingkungan kerja secara simultan berpengaruh positif dan signifikan terhadap kinerja karyawan pada PT. Inti Dufree Promosindo di Denpasar.

\section{Kata Kunci: Kompensasi, Lingkungan Kerja, Kinerja Karyawan}

\section{Pendahuluan}

Sumber daya manusia merupakan faktor utama dalam perusahaan untuk mencapai tujuan perusahaan. Tujuan perusahaan akan lebih mudah tercapai apabila di dalam perusahaan terdapat sumber daya manusia yang berpotensi dan kompeten, sehingga dapat memberikan peningkatan mutu dan kualitas perusahaan. Keberhasilan suatu perusahaan akan terlihat dengan jelas apakah dapat mengelola sumber daya manusia yang ada menjadi lebih baik dari sebelumnya dalam mencapai tujuan perusahaan.

Terkhusus pada faktor manusia, faktor ini memegang peranan yang sangat penting dalam pelaksanaan kegiatan perusahaan. Oleh karena itu, pihak perusahaan harus selalu memperhatikan faktor manusia atau tenaga kerja yang dapat menentukan keberhasilan perusahaan dalam mencapai tujuannya. Keberhasilan suatu perusahaan salah satunya dapat dilihat dari bagaimana kinerja perusahaan tersebut dan kinerja dari para sumber daya manusia atau karyawan yang berada dalam perusahaan. Tercapainya tujuan perusahaan tidak hanya tergantung pada peralatan modern, sarana dan prasarana yang lengkap, tetapi justru lebih tergantung pada manusia yang melaksanakan pekerjaan tersebut. Keberhasilan suatu organisasi sangat dipengaruhi oleh kinerja individu karyawannya. Setiap organisasi atau perusahaan akan selalu berusaha untuk meningkatkan kinerja karyawan, dengan harapan apa yang menjadi tujuan perusahaan akan tercapai (Nuraeni \& Irawati, 2020).

Kinerja mengacu pada prestasi karyawan yang diukur berdasarkan standar atau kriteria yang ditetapkan perusahan (Nuraeni \& Irawati, 2020). Kinerja karyawan adalah hasil kerja yang dicapai seseorang atau kelompok orang sesuai dengan wewenang/tanggung jawab masing-masing karyawan selama periode tertentu (Widyani \& Putra, 2020). Kinerja karyawan merupakan faktor penting dalam pelaksanaan tujuan perusahaan dan juga bermanfaat bagi pengembangan organisasi atau perusahaan agar mampu bersaing dan unggul dalam bersaing (Sulthan Muhammad Fauzan \& Sary, 2020). Sehingga dapat disimpulkan semakin naik kinerja karyawan maka semakin naik dan berkembang pula kinerja perusahaan.

Tujuan peningkatan kinerja antara lain peningkatan kinerja, penyesuaian kompensasi, keputusan penempatan, pelatihan dan kebutuhan pengembangan. perencanaan dan pengembangan karir, kekurangan proses kekaryawanan, ketidakakuratan informasi dan kesalahan desain pekerjaan, kesempatan kerja yang setara, umpan balik, dan tantangan eksternal (Yuningsih, dkk., 2020). Terdapat berbagai faktor yang mempengaruhi kinerja karyawan diantaranya, fakor internal karyawan yaitu faktor yang ada dalam diri karyawan yang merupakan faktor bawaan dari lahir, faktor lingkungan internal organisasi yang merupakan dukungan dari oeganisasi dimana dia bekerja, faktor lingkungan eksternal organisasi yaitu dukungan eksternal organisasi yang mempengaruhi kinerja karyawan (Sihaloho \& Siregar, 2019).

\section{Telaah Literatur dan Kajian Pustaka}

Kinerja Karyawan

Kinerja mengacu pada prestasi karyawan yang diukur berdasarkan standar atau kriteria yang ditetapkan perusahan (Nuraeni \& Irawati, 2020). Kinerja karyawan adalah hasil kerja yang dicapai seseorang atau kelompok orang sesuai dengan wewenang/ tanggung jawab masing-masing karyawan selama periode tertentu (Candana, dkk., 2020). Kinerja merupakan 
kondisi yang harus diketahui dan diinformasikan kepada pihak-pihak tertentu untuk mengetahui tingkat pencapaian hasil suatu instansi dihubungkan dengan visi yang diemban suatu organisasi serta menegtahui dampak positif dan negatif suatu kebijakan operasional yang diambil (Maryani, dkk., 2020).

Kompensasi

Kompensasi merupakan pemberian balas jasa langsung dan tidak langsung berbentuk uang atau barang kepada karyawan sebagai imbal jasa yang diberikannya kepada perusahaan (Sulthan Muhammad Fauzan \& Sary, 2020). Kompensasi merupakan gambaran ganti rugi yang diberikan oleh penerima jasa atau tenaga yang dihasilkan oleh tenaga kerja, penganti dari kontribusi jasa yang diberikan tenaga kerja oleh pihak yang memperoleh manfaat dari pelaksaanan tugas yang dilaksanakan (Yuningsih dkk., 2020). Kompensasi merupakan keseluruhan imbalan yang diterima oleh karyawan sebagai penghargaan atas kontribusi yang diberikan kepada organisasi, baik yang bersifat finansial maupun nonfinansial (Thamrin, dkk., 2020).

Lingkungan kerja

Lingkungan kerja merupakan salah satu tempat yang paling sering dilakukan oleh karyawan dalam melakukan kegiatan aktivitasnya sehari-hari (Rahardjo, 2014). Lingkungan kerja yang menyenangkan akan memberikan rasa nyaman kepada karyawan sehingga dapat mempengaruhi meningkatnya kinerja karyawan (Sihaloho \& Siregar, 2019). Lingkungan kerja merupakan semua bahan dan alat perkakas yang ada di sekeliling tempat orang bekerja yang mampu mempengaruhi metode kerjanya dan peraturan kerja baik sebagai individu maupun kelompok (Pawirosumarto, dkk., 2017).

Hipotesis penelitian dirumuskan bahwa, H1. diduga kompensasi secara parsial berpengaruh positif dan signifikan terhadap kinerja karyawan pada PT. Inti Dufree Promosindo di Denpasar; H2. diduga lingkungan kerja secara parsial berpengaruh positif dan signifikan terhadap kinerja karyawan pada PT. Inti Dufree Promosindo di Denpasar; H3. Diduga kompensasi dan lingkungan kerja secara simultan berpengaruh positif dan signifikan terhadap kinerja karyawan pada PT. Inti Dufree Promosindo di Denpasar.

\section{Metode Penelitian}

Pendekatan yang digunakan dalam penelitian ini adalah pendekatan kuantitatif yang berbentuk deskriptif, dimana dalam penelitian ini dilakukan pengamatan pada beberapa variabel untuk menggambarkan sesuatu dari variabel yang diteliti secara khusus. Lokasi penelitian dilakukan pada PT. Inti Dufree Promosindo yang berlokasi di Jalan Bypass Ngurah Rai, Kuta, Simpang Dewa Ruci, Sesetan, Kecamatan Denpasar Selatan, Kota Denpasar 80361. Variabel penelitian dibedakan menjadi variabel bebas yaitu kompensasi (X1) dan lingkungan kerja (X2), dan variabel terikat yaitu kinerja karyawan (Y).

Populasi dalam penelitian ini adalah seluruh karyawan yang masih aktif bekerja pada PT. Inti Dufree Promosindo di Denpasar sebanyak 306 orang karyawan. Metode penentuan sampel dalam penelitian ini menggunakan metode purposive sampling yaitu pengambilan sampel dengan berdasarkan kriteria tertentu yaitu karyawan PT. Inti Dufree Promosindo di Denpasar yang bekerja di 6 bagian shop perusahaan yaitu beauty, boutique, fashion watch, fine watch, food \& liqueur, dan destination sebanyak 86 orang karyawan. Accidental sampling digunakan dengan memberikan kuesioner kepada karyawan bagian shop PT. Inti Dufree Promosindo di Denpasar sebanyak 86 orang yang ditemui secara kebetulan. Untuk menjawab hipotesis yang telah diajukan baik hipotesis parsial (H1 dan $\mathrm{H} 2)$ maupun hipotesis simultas (H3) digunakan analisis regresi linear berganda. 


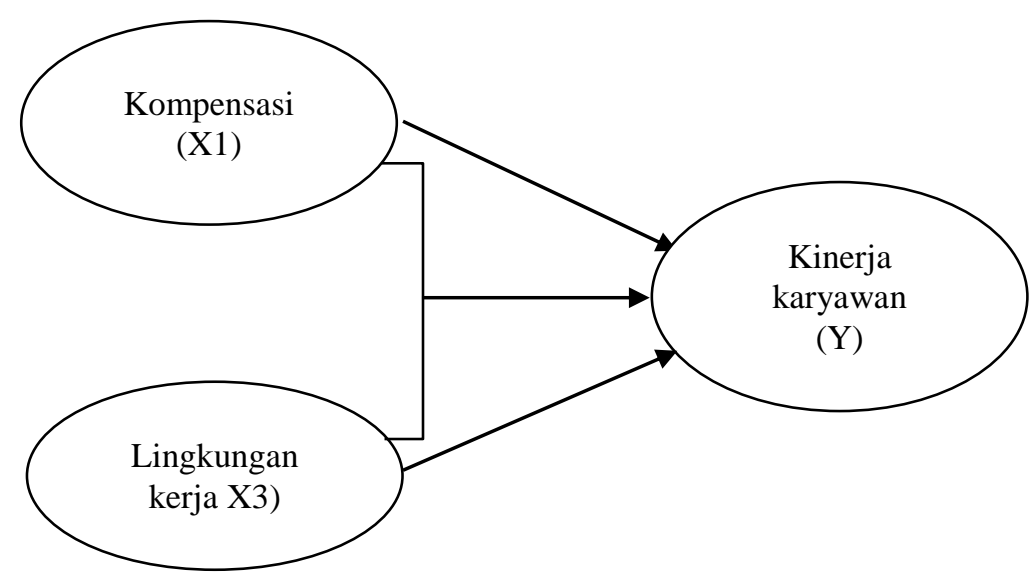

Gambar 1. Kerangka Konseptual

\section{Hasil Penelitian dan Pembahasan}

Tabel 1. Hasil Uji Validitas dan Reliabilitas Instrumen Penelitian

\begin{tabular}{|c|c|c|c|c|c|c|}
\hline \multirow[b]{2}{*}{ No } & \multirow[b]{2}{*}{ Variabel } & \multirow[b]{2}{*}{ Item Pernyataan } & \multicolumn{2}{|c|}{ Validitas } & \multicolumn{2}{|c|}{ Reliabilitas } \\
\hline & & & $\begin{array}{c}\text { Pearson } \\
\text { Correlation }\end{array}$ & Ket. & $\begin{array}{c}\text { Alpha } \\
\text { Cronbach }\end{array}$ & Ket. \\
\hline \multirow{9}{*}{1} & \multirow{9}{*}{$\begin{array}{c}\text { Kinerja Karyawan } \\
(\mathrm{Y})\end{array}$} & Y1 & 0,826 & Valid & \multirow{9}{*}{0,859} & \multirow{9}{*}{ Reliabel } \\
\hline & & Y2 & 0,770 & Valid & & \\
\hline & & Y3 & 0,689 & Valid & & \\
\hline & & Y4 & 0,770 & Valid & & \\
\hline & & Y5 & 0,716 & Valid & & \\
\hline & & Y6 & 0,595 & Valid & & \\
\hline & & Y7 & 0,596 & Valid & & \\
\hline & & Y8 & 0,572 & Valid & & \\
\hline & & Y9 & 0,629 & Valid & & \\
\hline \multirow{8}{*}{2} & \multirow{8}{*}{$\begin{array}{l}\text { Kompensasi } \\
\qquad\left(\mathrm{X}_{1}\right)\end{array}$} & $\mathrm{X} 1.1$ & 0,774 & Valid & \multirow{8}{*}{0,874} & \multirow{8}{*}{ Reliabel } \\
\hline & & $\mathrm{X} 1.2$ & 0,840 & Valid & & \\
\hline & & $\mathrm{X} 1.3$ & 0,792 & Valid & & \\
\hline & & $\mathrm{X} 1.4$ & 0,534 & Valid & & \\
\hline & & $X 1.5$ & 0,828 & Valid & & \\
\hline & & $\mathrm{X} 1.6$ & 0,765 & Valid & & \\
\hline & & $\mathrm{X} 1.7$ & 0,594 & Valid & & \\
\hline & & $\mathrm{X} 1.8$ & 0,900 & Valid & & \\
\hline \multirow{6}{*}{3} & & $\mathrm{X} 2.1$ & 0,868 & Valid & \multirow{6}{*}{0,909} & \multirow{6}{*}{ Reliabel } \\
\hline & & $\mathrm{X} 2.2$ & 0,736 & Valid & & \\
\hline & Lingkungan Kerja & $\mathrm{X} 2.3$ & 0,801 & Valid & & \\
\hline & $\left(\mathrm{X}_{2}\right)$ & X2.4 & 0,897 & Valid & & \\
\hline & & $\mathrm{X} 2.5$ & 0,765 & Valid & & \\
\hline & & $\mathrm{X} 2.6$ & 0,897 & Valid & & \\
\hline
\end{tabular}

Sumber: data diolah, 2021

Berdasarkan Tabel 1, maka semua variabel memiliki nilai koefisien korelasi berada di atas 0,30 dan nilai koefisien alpha cronbach berada di atas 0,6 dengan demikian semua instrumen tersebut adalah valid dan reliabel, sehingga layak dijadikan instrumen penelitian. 
Tabel 2. Hasil Uji Normalitas

One-Sample Kolmogorov-Smirnov Test

\begin{tabular}{llr}
\hline & & Unstandardized Residual \\
\hline $\mathrm{N}$ & & 86 \\
Normal Parameters ${ }^{\mathrm{a}, \mathrm{b}}$ & Mean & .0000000 \\
& Std. Deviation & 3.46799673 \\
Most Extreme Differences & Absolute & .121 \\
& Positive & .119 \\
& Negative & -.121 \\
Kolmogorov-Smirnov Z & & 1.120 \\
Asymp. Sig. (2-tailed) & & .163 \\
\hline
\end{tabular}

Sumber: data diolah, 2021

Berdasarkan Tabel 2, hasil uji normalitas yang didapatkan dengan menggunakan uji Kolmogorov-Smirnov memiliki tingkat signifikansi sebesar 0,163>0,05 sehingga dapat dikatakan bahwa model regresi memenuhi asumsi normalitas.

Tabel 3. Hasil Uji Multikolinearitas

\begin{tabular}{|c|c|c|c|c|c|c|}
\hline \multicolumn{7}{|c|}{ Coefficients $^{\mathrm{a}}$} \\
\hline & & \multicolumn{2}{|c|}{ Unstandardized Coefficients } & \multirow{2}{*}{$\begin{array}{c}\begin{array}{c}\text { Standardized } \\
\text { Coefficients }\end{array} \\
\text { Beta }\end{array}$} & \multicolumn{2}{|c|}{ Collinearity Statistics } \\
\hline \multicolumn{2}{|c|}{ Model } & $B$ & Std. Error & & Tolerance & VIF \\
\hline \multirow[t]{3}{*}{1} & (Constant) & 6.498 & 3.414 & & & \\
\hline & $\mathrm{X} 1$ & .244 & .088 & .197 & 1.000 & 1.000 \\
\hline & $\mathrm{x} 2$ & .912 & .089 & .732 & 1.000 & 1.000 \\
\hline
\end{tabular}

Sumber: data diolah, 2021

Berdasarkan Tabel 3 dapat dilihat bahwa seluruh variabel bebas memiliki nilai VIF kurang dari 10 dan mempunyai angka tolerance lebih dari 0,1 . Hal ini berarti bahwa tidak terdapat gejala multikolinearitas dari model regresi yang digunakan.

Tabel 4. Hasil Uji Heteroskedastisitas

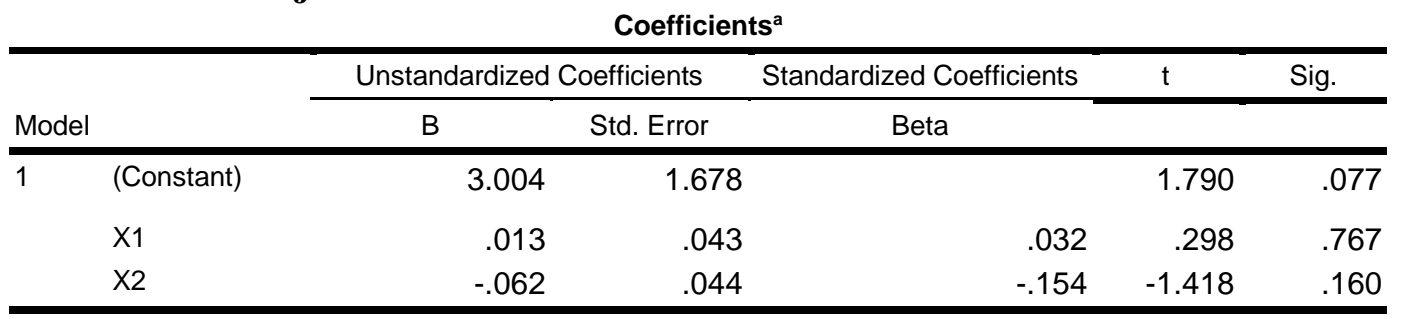

Sumber: data diolah, 2021

Berdasarkan Tabel 4 diketahui bahwa semua variabel memiliki tingkat signifikansi lebih besar dari 0,05. Hal ini berarti pada model regresi tidak terdapat gejala heteroskedastisitas.

\section{Hasil Analisis Regresi Linier Berganda}

Pengujian hipotesis dilakukan untuk menguji hipotesis yang diajukan. Hipotesis yang diajukan dalam penelitian ini terkait pengaruh kompensasi dan lingkungan kerja terhadap kinerja karyawan. 
Tabel 5. Hasil Analisis Regresi Linier Berganda

\begin{tabular}{|c|c|c|c|c|c|c|}
\hline \multicolumn{7}{|c|}{ Coefficients $^{a}$} \\
\hline \multirow[b]{2}{*}{ Model } & & \multicolumn{2}{|c|}{ Unstandardized Coefficients } & \multirow{2}{*}{$\begin{array}{c}\begin{array}{c}\text { Standardized } \\
\text { Coefficients }\end{array} \\
\text { Beta }\end{array}$} & \multirow[b]{2}{*}{$\mathrm{t}$} & \multirow[b]{2}{*}{ Sig. } \\
\hline & & $B$ & Std. Error & & & \\
\hline 1 & (Constant) & 6.498 & 3.414 & & 1.903 & .060 \\
\hline & $\mathrm{X} 1$ & .244 & .088 & .197 & 2.765 & .007 \\
\hline & $\mathrm{x} 2$ & .912 & .089 & .732 & 10.267 & .000 \\
\hline
\end{tabular}

Sumber: data diolah, 2021

Berdasarkan Tabel 5. diperoleh nilai konstanta $(\alpha)=6,498$ dan koefisien regresi $\left(\beta_{1}\right)=$ 0,244 dan $\left(\beta_{2}\right)=0,912$. Berdasarkan nilai-nilai tersebut di atas, maka diperoleh persamaan regresi linier berganda sebagai berikut:

$$
\mathrm{Y}=6,498+0,244 \mathrm{X}_{1}+0,912 \mathrm{X}_{2}
$$

Dari persamaan tersebut di atas, dapat diartikan sebagai berikut:

Nilai $\alpha=6,498$ yang berarti apabila nilai variabel kompensasi dan lingkungan kerja tidak meningkat, maka kinerja karyawan akan tetap sebesar 6,498. Nilai $\beta_{1}=0,244$ yang menunjukkan koefisien positif, yang berarti apabila nilai variabel kompensasi meningkat sebesar satu satuan, maka akan diikuti dengan peningkatan nilai variabel kinerja karyawan sebesar 0,244 satuan, dengan asumsi variabel lingkungan kerja tetap. Nilai $\beta_{2}=0,912$ yang menunjukkan koefisien positif, yang berarti apabila nilai variabel lingkungan kerja meningkat sebesar satu satuan, maka akan diikuti dengan peningkatan nilai variabel kinerja karyawan sebesar 0,912 satuan, dengan asumsi variabel kompensasi tetap. Dilihat dari nilai $\left(\beta_{1}\right)=0,244$ dan $\left(\beta_{2}\right)=0,912$ yang berarti apabila nilai variabel kompensasi dan lingkungan kerja samasama meningkat sebesar satu satuan, maka akan diikuti dengan peningkatan nilai variabel kinerja karyawan sebesar 1,156 satuan.

Analisis determinasi adalah suatu analisis untuk mengetahui seberapa besar pengaruh secara simultan dari kompensasi dan lingkungan kerja terhadap kinerja karyawan PT. Inti Dufree Promosindo di Denpasar.

\section{Tabel 6. Hasil Analisis Determinasi}

Model Summary

\begin{tabular}{lrrrrr}
\hline Model & $\mathrm{R}$ & $\mathrm{R}$ Square & Adjusted R Square & \multicolumn{2}{c}{ Std. Error of the Estimate } \\
\hline 1 & $.760^{\mathrm{a}}$ & .578 & .568 & 3.510 \\
\hline
\end{tabular}

Sumber: data diolah, 2021

Dengan demikian besarnya pengaruh kompensasi dan lingkungan kerja terhadap kinerja karyawan PT. Inti Dufree Promosindo di Denpasar adalah sebesar 57,8\% sedang sisanya $42,2 \%$ dipengaruhi faktor-faktor lain yang tidak diteliti misalnya motivasi kerja, semangat kerja, dan lainnya.

1. Pengaruh Kompensasi Terhadap Kinerja Karyawan

Hasil pengujian t-test pengaruh kompensasi terhadap kinerja karyawan PT. Inti Dufree Promosindo di Denpasar diperoleh nilai koefisien regresi sebesar 0,244 dan menunjukkan nilai thitung sebesar 2,765 > ttabel sebesar 1,989 serta nilai signifikan uji t sebesar 0,007 yang lebih kecil dari $\alpha$ (taraf nyata) $=0,05$, maka dapat disimpulkan bahwa kompensasi berpengaruh positif dan signifikan terhadap kinerja karyawan PT. Inti Dufree Promosindo di Denpasar.

Hasil penelitian ini sejalan dengan hasil penelitian sebelumnya yang dilakukan oleh Maryani dkk., (2020) menyatakan bahwa baik kompensasi finansial maupun kompensasi non 
finansial merupakan variabel yang berpengaruh terhadap kinerja karyawan. Hasil penelitian ini juga didukung dengan penelitian Hendro (2018) menyatakan kompensasi berpengaruh signifikan secara parsial dan simultan terhadap kinerja karyawan. Serta penelitian Kurniawati dan Fitriyani (2018) yang menyatakan kompensasi berpengaruh positif dan signifikan secara parsial terhadap kinerja karyawan. Perusahaan yang memberikan kompensasi yang layak kepada karyawannya dan karyawan juga mematuhi segala peraturan yang diberikan perusahaan maka akan memberikan dampak yang baik dalam meningkatkan kinerja karyawan. Pada PT. Inti Dufree Promosindo di Denpasar karyawan masih merasa belum mendapatkan gaji yang seimbang dengan beban kerja, hal ini lah yang menyebabkan belum maksimalnya kinerja karyawan pada PT. Inti Dufree Promosindo di Denpasar khususnya tingkat absensi yang tinggi karena karyawan malas bekerja mengingat kompensasi yang dirasa tidak sesuai dengan beban kerja, untuk itu PT. Inti Dufree Promosindo di Denpasar diharapkan dapat menentukan kompensasi melihat dari beban kerja masing-masing karyawan untuk membangkitkan semangat kerja karyawan dan mendapatkan kinerja yang lebih baik.

2. Pengaruh Lingkungan Kerja Terhadap Kinerja Karyawan

Hasil pengujian t-test pengaruh lingkungan kerja terhadap kinerja karyawan PT. Inti Dufree Promosindo di Denpasar diperoleh nilai koefisien regresi sebesar 0,912 dan menunjukkan nilai t-hitung untuk variabel lingkungan kerja sebesar 10,267 > t-tabel sebesar 1,989 serta nilai signifikan uji t sebesar 0,000 yang lebih kecil dari $\alpha$ (taraf nyata) $=0,05$, maka dapat disimpulkan bahwa lingkungan kerja berpengaruh positif dan signifikan terhadap kinerja karyawan PT. Inti Dufree Promosindo di Denpasar.

Hasil penelitian ini sejalan dengan hasil penelitian sebelumnya yang dilakukan oleh Kristanti (2017) menyatakan bahwa lingkungan kerja fisik dan lingkungan kerja non fisik secara parsial maupun simultan berpengaruh positif dan signifikan terhadap kinerja karyawan. Hasil penelitian ini juga didukung dengan penelitian Saptadi dan Widarko (2017) yang menyatakan lingkungan kerja berdampak positif terhadap kinerja karyawan. Serta penelitian Sulistiawan dkk. (2018) dan Deswita (2018) yang juga menyatakan lingkungan kerja berpengaruh positif dan signifikan terhadap kinerja karyawan. Kondisi lingkungan kerja dikatakan baik atau sesuai apabila manusia dapat melaksanakan kegiatan secara optimal, sehat, aman, dan nyaman. Kesesuaian lingkungan kerja dapat dilihat akibatnya dalam jangka waktu yang lama lebih jauh lagi lingkungan-lingkungan kerja yang kurang baik dapat menuntut tenaga kerja dan waktu yang lebih banyak dan tidak mendukung diperolehnya rancangan sistem kerja yang efisien. Lingkungan kerja di PT. Inti Dufree Promosindo di Denpasar dirasa masih kurang terutama tingkat kebersihan, banyaknya pengunjung membuat karyawan harus bekerja lebih untuk menjaga kebersihan. Keadaan yang kurang bersih tersebut karyawan tidak dapat bekerja dengan baik sehingga membuat kinerja karyawan PT. Inti Dufree Promosindo di Denpasar menjadi belum maksimal dengan melihat masih ada pekerjaan yang belum dapat diselesaikan dengan baik.

Tabel 7. Uji Simultan (F-test)

\begin{tabular}{llrrrrr}
\hline \multicolumn{7}{c}{ ANOVA $^{\mathrm{b}}$} \\
Model & & Sum of Squares & df & Mean Square & F & Sig. \\
\hline 1 & Regression & 1399.705 & 2 & 699.852 & 56.821 & $.000^{\mathrm{a}}$ \\
& Residual & 1022.295 & 83 & 12.317 & & \\
& Total & 2422.000 & 85 & & & \\
\hline
\end{tabular}

Sumber: data diolah, 2021 


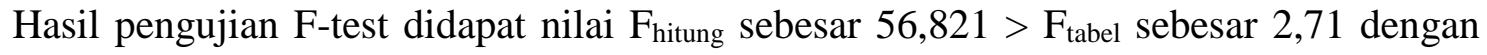
signifikansi 0,000 lebih kecil dari $\alpha$ (taraf nyata) $=0,05$, maka dapat disimpulkan bahwa kompensasi dan lingkungan kerja berpengaruh positif dan signifikan terhadap kinerja karyawan PT. Inti Dufree Promosindo di Denpasar, sehingga hipotesis ketiga (H3) yang menyatakan bahwa kompensasi dan lingkungan kerja secara simultan berpengaruh signifikan terhadap kinerja karyawan PT. Inti Dufree Promosindo di Denpasar dapat diterima.

Hasil penelitian ini sejalan dengan hasil penelitian sebelumnya yang dilakukan oleh Deswita (2018) yang menyatakan kompensasi dan lingkungan kerja secara simultan berpengaruh signifikan terhadap kinerja karyawan. Hasil penelitian ini juga didukung dengan penelitian Saptadi dan Widarko (2017) yang juga menyatakan bahwa bahwa kompensasi dan lingkungan kerja secara simultan berpengaruh signifikan terhadap kinerja karyawan. Pemberian kompensasi yang sesuai dengan beban kerja karyawan serta didukung dengan lingkungan kerja yang kondusif maka akan meningkatkan kinerja karyawan, karena karyawan akan merasa termotivasi untuk bekerja lebih baik dari sebelumnya. Melihat kompensasi yang lingkungan kerja yang sangat mempengaruhi kinerja karyawan, serta kinerja karyawan PT. Inti Dufree Promosindo di Denpasar yang masih belum maksimal tentunya perbaikan sistem pembagian kompensasi dan perbaikan lingkungan kerja khususnya tingkat kebersihan dapat menjadi prioritas bagi PT. Inti Dufree Promosindo di Denpasar untuk meningkatkan kinerja karyawan ke arah yang lebih baik.

\section{Simpulan}

Hasil analisis hipotesis pertama menunjukkan bahwa pengaruh kompensasi terhadap kinerja karyawan diperoleh koefisien regresi sebesar 0,244, nilai thitung sebesar 2,765 $>t_{\text {tabel }}$ sebesar 1,989 serta nilai signifikan uji t sebesar 0,007 < 0,05, sehingga H1 diterima. Maka dapat disimpulkan bahwa kompensasi berpengaruh positif dan signifikan terhadap kinerja karyawan PT. Inti Dufree Promosindo di Denpasar.

Hasil analisis hipotesis kedua menunjukkan bahwa pengaruh lingkungan kerja terhadap kinerja karyawan diperoleh koefisien regresi sebesar 0,912, nilai $t_{\text {hitung }}$ sebesar 10,267 $>t_{\text {tabel }}$ sebesar 1,989 serta nilai signifikan uji t sebesar $0,000<0,05$, sehingga $\mathrm{H} 2$ diterima. Maka dapat disimpulkan bahwa lingkungan kerja berpengaruh positif dan signifikan terhadap kinerja karyawan PT. Inti Dufree Promosindo di Denpasar.

Hasil analisis hipotesis ketiga menunjukkan bahwa pengaruh kompensasi dan lingkungan kerja secara bersama-sama terhadap kinerja karyawan diperoleh nilai $\mathrm{F}$ hitung sebesar 56,821 $>F_{\text {tabel }}$ sebesar 2,71 dengan signifikansi $0,000<0,05$. Nilai koefisien determinasi didapat 57,8\% sedangkan sisanya sebesar 42,2\% dipengaruhi oleh faktor lain yang tidak diteliti dalam penelitian ini. Maka dapat disimpulkan bahwa kompensasi dan lingkungan kerja secara simultan berpengaruh positif dan signifikan terhadap kinerja karyawan PT. Inti Dufree Promosindo di Denpasar. 


\section{$\underline{\text { Daftar Pustaka }}$}

Candana, D. M., Putra, R. B., \& Wijaya, R. A. (2020). PENGARUH MOTIVASI DAN LINGKUNGAN KERJA TERHADAP KINERJA KARYAWAN DENGAN DISIPLIN KERJA SEBAGAI VARIABEL INTERVENING PADA PT BATANG HARI BARISAN. Jurnal Ekonomi Manajemen Sistem Informasi, 2(1), 47-60.

Deswita, P. (2018). PENGARUH KOMPENSASI, SEMANGAT KERJA DAN LINGKUNGAN KERJA TERHADAP KINERJA PEGAWAI DINAS PENDIDIKAN DAN KEBUDAYAN KABUPATEN INDRAGIRI HULU. MAP (Jurnal Manajemen Dan Administrasi Publik), 1(01), 101-109.

Hendro, T. (2018). Pengaruh Kompensasi Dan Kepuasan Kerja Terhadap Kinerja Karyawan

Tetap CV. Karya Gemilang. Agora, 6(1).

Kristanti, E. (2017). Pengaruh Lingkungan Kerja Fisik dan Lingkungan Kerja Non Fisik

Terhadap Stres Kerja dan Dampaknya Terhadap Kinerja Karyawan (Studi Pada Kantor

Bersama Samsat Mojokerto Kota). Jurnal Ilmu Manajemen, 5(1), 1-10. https://jurnalmahasiswa.unesa.ac.id/index.php/jim/article/view/18108

Kurniawati, D., Fitriyani, \& Meifi, L. (2017). Pengaruh Kompensasi Dan Disiplin Kerja Terhadap Kinerja Karyawan Di Pt. Marinal Indoprima Desa Kapedi Sumenep. Wacana Equiliberium: Jurnal Pemikiran \& Penelitian Ekonomi, 33-42.

Maryani, N. L. K. S., Widyani, A. A. D., \& Saraswati, N. P. A. S. (2020). Pengaruh Kompensasi Finansial terhadap Kinerja Karyawan dengan Motivasi sebagai Variabel Intervening pada PT. Arta Sedana Retailindo Cabang Hardys Malls Sanur. Values, 1(2), 53-67. http://e-journal.unmas.ac.id/index.php/value/article/view/813

Nuraeni, Y. S., \& Irawati, D. (2020). PENGARUH KOMPENSASI, MOTIVASI, DAN KEPUASAN KERJA TERHADAP KINERJA KARYAWAN PADA CITRA GRAND HOTEL KARAWANG. Procuratio: Jurnal Ilmiah Manajemen, 8(3), 244-255.

Pawirosumarto, S., Sarjana, P. K., \& Gunawan, R. (2017). The effect of work environment, leadership style, and organizational culture towards job satisfaction and its implication towards employee performance in Parador hotels and resorts, Indonesia. International Journal of Law and Management, 59(6), 1337-1358. https://doi.org/10.1108/IJLMA-102016-0085

Rahardjo, S. (2014). The Effect of Competence, Leadership and Work Environment Towards Motivation and its Impact on the Performance of Teacher of Elementary School in Surakarta City, Central JAVA, Indonesia. International Journal of Advanced $\begin{array}{lllll}\text { Research in Management and Social Sciences, 3(6), 59-74. } & \text {. }\end{array}$ http://www.garph.co.uk/IJARMSS/June2014/7.pdf

Saptadi, S., \& Widarko, A. (2017). PENGARUH LINGKUNGAN KERJA BUDAYA ORGANISASI DAN KOMPENSASI TERHADAP KINERJA KARYAWAN (Studi Kasus Pada Sunrise Hotel Dusun Gili Air Desa Gili Indah Kec. Pemenang Kab. Lombok Utara NTB). Jurnal Ilmiah Riset Manajemen, 6(05).

Sihaloho, R. D., \& Siregar, H. (2019). Pengaruh Lingkungan Kerja Terhadap Kinerja Karyawan pada PT Super Setia Sagita Medan. Jurnal Ilmiah Socio Secretum, 9(2), 273281. https://jurnal.darmaagung.ac.id/index.php/socio/article/view/413/406

Sulistiawan, D., Riadi, S. S., \& Maria, S. (2018). Pengaruh budaya organisasi dan lingkungan kerja terhadap kinerja pegawai. KINERJA, 14(2), 61-69.

Sulthan Muhammad Fauzan, \& Sary, F. P. (2020). Pengaruh Kompensasi Terhadap Kinerja Karyawan (Studi Kasus Pada Bank Bjb Cabang Utama Bandung). Jurnal Mitra Manajemen, 4(6), 928-937. https://doi.org/10.52160/ejmm.v4i6.403 
Thamrin, M. F., Semmaila, B., \& Aminuddin. (2020). Pengaruh Kepemimpinan, Kompensasi dan Motivasi Kerja Terhadap Kinerja Karyawan PT. Bank Rakyat Indonesia Unit Salo Cabang Pinrang. Paradoks: Jurnal Ilmu Ekonomi, 3(2), 148-156.

Widyani, A. A. D., \& Putra, I. W. A. P. (2020). Pengaruh Rekrutmen dan Promosi Jabatan Terhadap Kinerja Karyawan Pada PT. Bank Sinarmas Cabang Denpasar. Widya Manajemen, 2(1), 80-88.

Yuningsih, E., Harini, S., \& Rifky, M. G. (2020). Pengaruh Motivasi Kerja Dan Kompensasi Terhadap Kinerja Karyawan Pada Divisi Produksi Pt. Kusuma Kaisan Sentul-Bogor. Jurnal Visionida, 6(1), 47. https://doi.org/10.30997/jvs.v6i1.2746 